Review

\title{
Review of Artificial Intelligence Applied in Decision-Making Processes in Agricultural Public Policy
}

\author{
Juan M. Sánchez ${ }^{1, * \mathbb{C}}$, Juan P. Rodríguez ${ }^{2, * \mathbb{C}}$ and Helbert E. Espitia ${ }^{1}$ (1) \\ 1 Facultad de Ingeniería, Universidad Distrital Francisco José de Caldas, 11021-110231588 Bogotá, Colombia; \\ heespitiac@udistrital.edu.co \\ 2 Facultad del Medio Ambiente y Recursos Naturales, Universidad Distrital Francisco José de Caldas, \\ 110321 Bogotá, Colombia \\ * Correspondence: jmsanchezc@udistrital.edu.co (J.M.S.); jprodriguezm@udistrital.edu.co (J.P.R.)
}

Received: 2 October 2020; Accepted: 20 October 2020; Published: 29 October 2020

\begin{abstract}
The objective of this article is to review how Artificial Intelligence (AI) tools have helped the process of formulating agricultural public policies in the world. For this, a search process was carried out in the main scientific repositories finding different publications. The findings have shown that, first, the most commonly used AI tools are agent-based models, cellular automata, and genetic algorithms. Secondly, they have been utilized to determine land and water use, and agricultural production. In the end, the large usefulness that AI tools have in the process of formulating agricultural public policies is concluded.
\end{abstract}

Keywords: agriculture; artificial intelligence; decision making; policy formulation; public policy

\section{Introduction}

The conceptual framework of this article consists of 3 areas of knowledge that are public policy, Artificial Intelligence (AI) and decision making, specifically framed in the agricultural sector. For a better understanding, the concept of public policy and its decision-making process are initially presented, as is how artificial intelligence has been applied in decision-making processes.

In order to understand the concept of public policy, [1] explains that there are the strategies and norms composed and implemented to solve collective problems and that the creation of these policies is based on social interest and the improvement of the quality of life. Therefore, all public policy generation processes basically have three stages: formulation, implementation, and evaluation. The formulation stage determines the best solutions to find the best implementation solution; thus, it is of utmost importance that the decision-making process in public policy is as assertive as possible. For this reason, various authors have elaborated several models on the decision-making process in this area, the main ones are summarized below.

The first model was postulated by Frederic Taylor, who established that decision making is based entirely on reason; this would imply that the agent always has to find the optimal solution. The second was developed by Helbert Simon, Nobel Prize in Economics, who determined that decision-making is partially irrational due to our cognition, information, and time limitations [2]. Another model was the one presented by Charles Lindblom, which clarifies that the public decision maker uses the knowledge acquired in past policies as a basis to foresee the probable consequences happening on the same line of action [3]. On the other hand, Michael D. Cohen, James G. March, and Johan P. Olsen explain that decision making in public policy belongs to a complex system due to the diversity of elements that the system has; additionally, many aspects occur at the same time and mix together, making it 
a confusing system, which Cohen, March, and Olson call an anarchic system [4]. Finally, the model proposed by J. Habermas is an ideal model since the decision making is done collectively with the participation of all being affected by the decision or of their representatives. This decision must be made through arguments offered by the participants, who are committed to the values of rationality and impartiality [5].

As presented, the different models developed have established elements that help and hinder the decision-making process in public policy; therefore, tools that contribute to improving, the decision-making process will be beneficial.

Currently, due to the significant development of Information Technologies (IT), tools have been created to help the decision-making process; among these are artificial intelligence, which has proven useful in improving decision-making process. AI has been used for business intelligence as in the investigations carried out by [6-8]. Research has also been carried out in the financial sector [9-13], for optimization of production processes such as in [14], and in human resources selection processes [15-18]. Besides, there are some works in environmental and land science, like those of [19-24]; in the health sector, as the ones carried out by [25-31]; in the education sector, as the one carried out by [32]; and in the judicial sector such as in [33]. Finally, in [34], the authors present how artificial intelligence techniques have been used in decision-making processes in different areas, taking as information the use of open data. There are many investigations in a large number of sectors and areas of knowledge. All of this research supports the effectiveness of $\mathrm{AI}$ in the decision-making process, which is why it is proposed to be of great use in the process of formulating public policies, specifically application in the agricultural sector.

Artificial intelligence tools have also been used to forecast different economic indicators, which will help to formulate economic policies and to improve the quality of life of citizens within a society. Some of these implementations are named below. The study of [35] applied an artificial feedback neural network to forecast financial data. They determined that this technique is beneficial for forecasting processes compared to traditional statistical methods. Meanwhile, in [36], the authors implemented Machine Learning (ML) models to predict future trade patterns of different countries. The research found that ML techniques made it possible to extract the best economic variables that would affect trade in specific commodities in different countries and to thus formulate better policies. The study of [37] proposed a system based on artificial neural networks to forecast the economic growth of the tertiary industry in Zhejiang (China). The study determined that the system offered better performance and efficiency than traditional methods. Additionally, in [38], the kernel ridge regression methodology was used to forecast economic time series, in which it was found that this methodology produces more accurate forecasts than traditional linear and nonlinear methods to deal with many predictors based on principal components.

Regarding the importance of using this technique, [39] analyzed whether the "black box"-type systems affect efficiency of the market; the authors examine the Italian motor vehicle insurance market using data provided by the Italian Insurance Authority; observations point out that, in the near future, the efficiency of this process may increase due to the specific use of (black box) information by allowing individual profile insurance policies.

Regarding the development of AI applications, [40] stated that this is an intensive process that requires the contribution of "micro-workers" that annotate, label, correct, and classify the data used to train and test the intelligent solutions. The authors consider the case of the automotive industry, one of the largest customers related to digital data, especially for the development of autonomous and networked cars. It is established that this work has a place in long supply chains, where technology companies compete with the more traditional industry players; it involves workers from different geographical and linguistic areas, requiring a joint study of multiple platforms that operate both globally and locally. 
According to [41], some nations have recognized the transformative potential of artificial intelligence, which will affect all facets of society. A series of published national AI strategic plans provides valuable information on how nations are considering future trajectories. These strategic plans offer evidence to understand national strategic actions, both proactive and reactive, in the face of rapid technological innovation. An interesting case on the coverage of public sector functions using AI is China, due to the impact of the public sector on the Chinese economy. In this way, China is expected to lead other nations when modernizing its public sector due to advances in AI.

In addition to this case, in [42], the state and prospects of the AI innovation ecosystem in China are analyzed by developing a Triple Helix framework based on an in-depth qualitative study and interviews with experts. The key characteristics of the Triple Helix are governments, industry and academic (research) institutions, as well as the dynamic context of the ecosystem through identification of the main aspects related to the flows of skills, knowledge, and funding and to the interactions between them. According to [42], there is a favorable context, a wide adoption rate, and competition for talent driving the advancement of AI in China, mainly in the field of customer business.

This article is structured as follows. First, Section 2 describes the methodology used to carry out the literature review. Section 3 presents some aspects of artificial intelligence and its main techniques. Section 4 briefly explains the concepts of agrarian public policy, its formulation, and its decision-making process. Section 5 presents how artificial intelligence has helped to improve the decision-making process in public policy and particularly in agrarian public policy. Finally, the discussion and conclusions are given.

\section{Methodology}

According to Tamayo in [43], the applied methodology is descriptive because it interprets the current situation of research in the area and the methodological approach is of a mixed nature as proposed by Creswell in [44], which integrates qualitative and quantitative methodologies. Qualitative methodology is used due to the subjective nature of the publication selection process and the categorization by the authors, quantitative methodology is used because a measurement of the data collected is carried out through indicators [43]. For the methodological design, elements were taken from the Preferred Reporting Items for Systematic Reviews and Meta-Analyses (PRISMA) statement used for systematic reviews and meta-analyses [45-47]. The PRISMA method is recommended by many researchers and publishers for the development of review articles. The methodological design can be seen in Figure 1, which has 4 main stages; the first is information gathering, the second is data preparation, the third is results and analysis, and the last stage corresponds to the discussion and conclusions. 


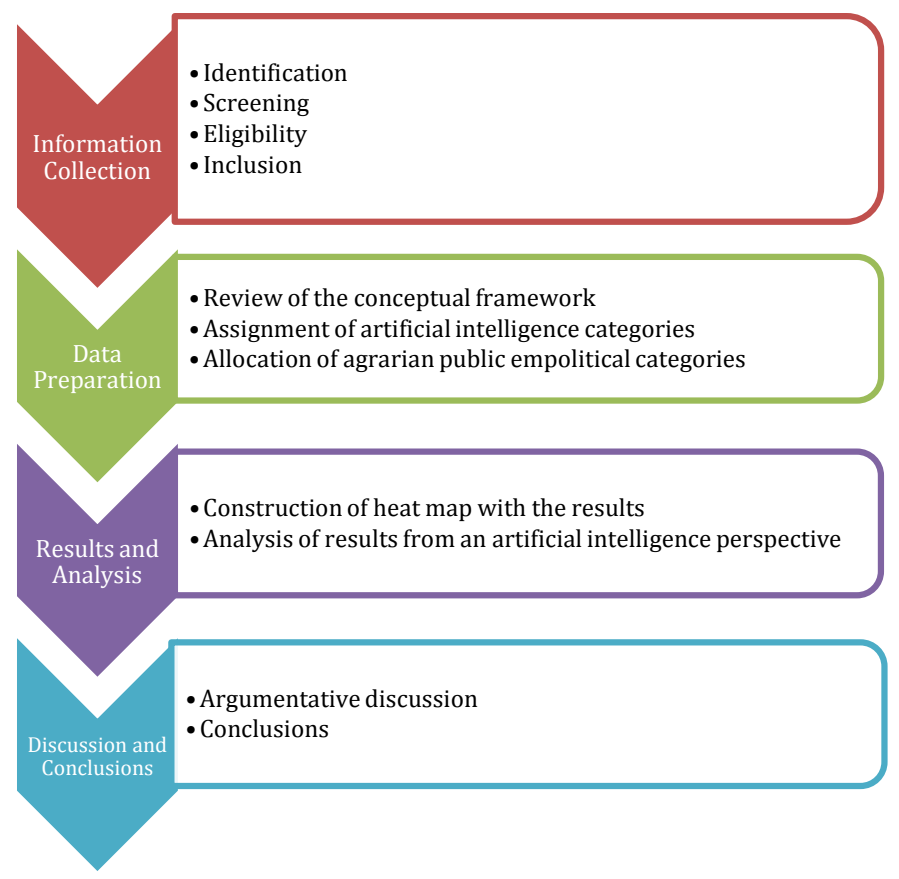

Figure 1. Methodological design.

\subsection{Information Collection}

The PRISMA method was used for this stage since it ensures transparency of the procedure [48]. PRISMA is divided into four phases: (a) identification, (b) screening, (c) eligibility, and (d) inclusion. The objective of the identification phase is to determine how artificial intelligence tools have been used for decision making in the process of formulating agricultural public policies. The information search was carried out in the SCOPUS database to find scientific publications related to the matter in internationally recognized journals. The search items used were according to the research topics; these are artificial intelligence, decision making, public policies, and agriculture. The search metadata to which the terms were applied were "Title", "Keywords", and "Abstract". With these parameters, the search equation used was TITLE-ABS-KEY ("artificial intelligence" OR "cybernetics" OR "neural network" OR "fuzzy logic" OR "machine learning" OR "data Mining" OR "expert systems" OR "genetic algorithms" OR "neuro-fuzzy" OR "agent-based model" OR "cellular automata" OR "Bayesian networks") AND TITLE-ABS-KEY ("public poli*" OR "national poli*” OR "government poli*” OR "political decision-mak" OR "policy mak") AND TITLE-ABS-KEY ("decision mak*" OR "decision supp"”) AND TITLE-ABS-KEY (“Agricultur" OR “agro*” OR “agrarian” OR “farm*”) AND NOT TITLE-ABS-KEY (milk). The search period included publications from the years 2001 to 2020. The search was carried out on 15 April 2020; in the search, 110 related publications were found. The inclusion and exclusion criteria are named respectively in Tables 1 and 2.

All bibliometric data were stored in an Excel file including the abstract. The full versions of the publications that were available and the summary versions of the other articles were also stored in the Mendeley reference management software.

The screening phase employed the inclusion and exclusion criteria presented in Tables 1 and 2; it was manually verified with titles and abstracts, which made it possible to identify inaccuracies in the publications. In this phase, the 110 publications were reduced to 98 . Subsequently, the eligibility phase was carried out on the sample obtained in the previous phase, applying the same controls, but on the full text of all samples. After this stage, 82 publications remained. Finally, in the inclusion phase, the remaining studies were thoroughly analyzed, obtaining 71 publications. The information gathering stage using the PRISMA method is seen in Figure 2. The manual process consisted of each 
author performing verification of the publications individually and then socializing and reaching a consensus for their selection.

Table 1. Inclusion criteria.

\begin{tabular}{l} 
Academic or commercial research focused on the adoption of AI as a solution for \\
decision making in the process of formulating agricultural public policies \\
\hline Presence of terms related to AI, according to an analysis of the conceptual framework: \\
artificial intelligence, cybernetics, neural network, fuzzy logic, machine learning, data \\
mining, expert systems, genetic algorithms, neuro-fuzzy, agent-based model, cellular \\
automaton, and Bayesian networks \\
\hline Presence of terms related to public policy: public policy, national policy, government \\
policy, political decision-making, and policy making \\
\hline Presence of terms related to decision making: decision making and decision support \\
\hline Presence of terms related to agriculture: agronomy, agrarian, agriculture, and farm \\
\hline Studies published in English between 1 January 2001 and 15 April 2020 \\
\hline
\end{tabular}

Table 2. Exclusion criteria.

\begin{tabular}{l}
\hline Publications prior to 1 January 2001 \\
\hline Investigations focused on private sector solutions that do not determine benefits to the \\
public sector or community citizens \\
\hline Research that only applies to the livestock sector
\end{tabular}

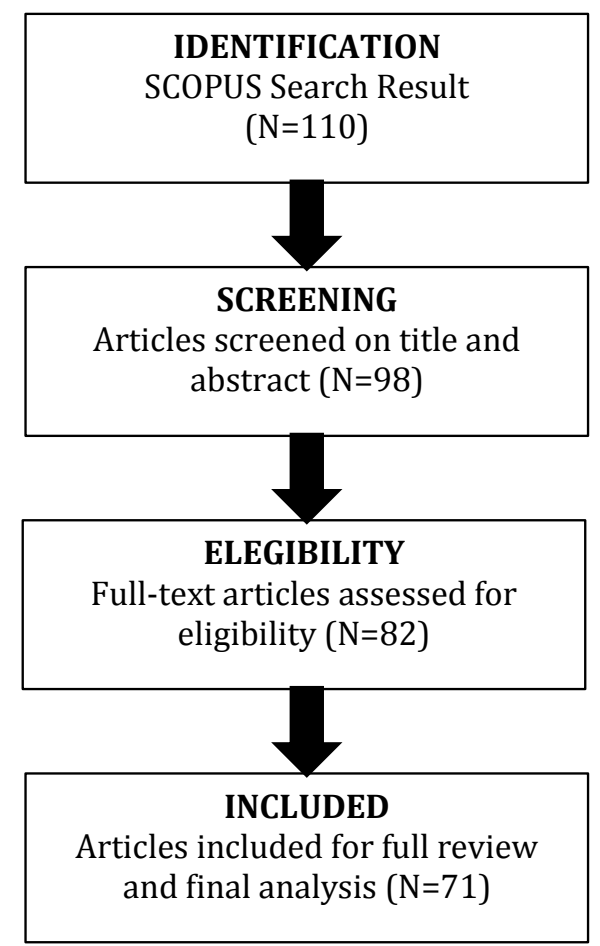

Figure 2. Preferred Reporting Items for Systematic Reviews and Meta-Analyses (PRISMA) flow chart. 


\subsection{Data Preparation}

At this stage, the conceptual framework of the research was taken as a basis and each publication was assigned categories corresponding to agricultural public policies and artificial intelligence tools; this process was subjective in accordance with the criteria of the authors, in which each author assigned the categories corresponding to each publication according to their criteria and then, by consensus among the authors, the definitive categories were assigned.

Definition of the categories related to artificial intelligence was made from a review of related literature using the PRISMA method; finally, a consultation with experts was carried out to validate the categorization identifying 7 categories. Regarding the categories related to the agricultural public policy variable, a systematic review of publications was carried out to find the main variables. A total of 100 related publications were reviewed. After this initial definition, consultation was carried out to experts in agrarian public policy to validate and synthesize the main variables used. Finally, 14 categories were defined, as shown in Figure 3. After the data preparation process, the results were obtained and analyzed.

\begin{tabular}{|c|c|c|c|c|c|c|c|c|}
\hline VARIABLES & $\begin{array}{c}\text { Agent } \\
\text { Based } \\
\text { Model } \\
\end{array}$ & $\begin{array}{c}\text { Cellular } \\
\text { Automata }\end{array}$ & $\begin{array}{c}\text { Support } \\
\text { Vector } \\
\text { Machine }\end{array}$ & $\begin{array}{c}\text { Evolutionary } \\
\text { Algorithms }\end{array}$ & $\begin{array}{c}\text { Artificial } \\
\text { Neural } \\
\text { Networks } \\
\end{array}$ & \begin{tabular}{|c|} 
Bayesian and \\
Markovs \\
Networks \\
\end{tabular} & $\begin{array}{l}\text { Fuzzy } \\
\text { Logic }\end{array}$ & TOTAL \\
\hline Land Use & 9 & 8 & 3 & 1 & 3 & 0 & 0 & 24 \\
\hline $\begin{array}{l}\text { Agricultural } \\
\text { Production }\end{array}$ & 2 & 2 & 4 & 4 & 2 & 1 & 2 & 17 \\
\hline Water Use & 3 & 1 & 1 & 3 & 2 & 2 & 4 & 16 \\
\hline $\begin{array}{c}\text { Weather/Climate } \\
\text { Change }\end{array}$ & 4 & 1 & 2 & 0 & 1 & 1 & 0 & 9 \\
\hline $\begin{array}{l}\text { Sustainable } \\
\text { Agriculture }\end{array}$ & 2 & 2 & 0 & 1 & 0 & 1 & 0 & 6 \\
\hline $\begin{array}{c}\text { Negative } \\
\text { Environmental } \\
\text { Impact Reduction }\end{array}$ & 4 & 0 & 0 & 1 & 0 & 0 & 0 & 5 \\
\hline Government Grants & 4 & 0 & 0 & 0 & 0 & 0 & 0 & 4 \\
\hline Food Safety & 1 & 1 & 1 & 0 & 1 & 0 & 0 & 4 \\
\hline $\begin{array}{c}\text { Ecological } \\
\text { Agriculture }\end{array}$ & 2 & 1 & 0 & 0 & 0 & 0 & 0 & 3 \\
\hline Fire Prevention & 2 & 0 & 0 & 0 & 0 & 0 & 0 & 2 \\
\hline Pest Management & 0 & 0 & 0 & 0 & 0 & 2 & 0 & 2 \\
\hline Agricultural policy & 1 & 0 & 0 & 0 & 0 & 0 & 0 & 1 \\
\hline Machinery Use & 1 & 0 & 0 & 0 & 0 & 0 & 0 & 1 \\
\hline Use of Energy & 0 & 0 & 0 & 0 & 1 & 0 & 0 & 1 \\
\hline TOTAL & 35 & 16 & 11 & 10 & 10 & 7 & 6 & 95 \\
\hline
\end{tabular}

Figure 3. Agricultural public policy variables and artificial intelligence techniques.

\subsection{Results and Analysis}

For of obtaining and analyzing the results, initially, a heat map with two axes was built, one axis presenting the categories corresponding to agricultural public policy and the second axis presenting the categories corresponding to artificial intelligence. The heat map is shown in Figure 3 . In the cell corresponding to the crossing of categories of the two axes, the number of corresponding publications is presented; a publication may be in more than one category because the related research may have dealt with various agricultural public policy issues or may have used more than one artificial intelligence technique in the study. The resulting heat map was analyzed from the perspective of 
artificial intelligence; likewise, the analysis included how each investigation used the technological tool to formulate agricultural public policy. The discussion proceeded after conducting a complete review of the publications.

\subsection{Discussion and Conclusions}

This stage consisted of carrying out an argumentative process obtained in the analysis of results compared to the conceptual framework in which the study is framed to finally obtain the conclusions of the study.

\section{Artificial Intelligence}

Artificial intelligence can be defined as "the capacity of a machine to perform cognitive functions associated with human minds, such as perceiving, reasoning, learning, interacting with the environment, solving problems, and even exercising creativity". [49]. The artificial intelligence expert system uses computational models that emulate the reasoning of experts. This system is based on knowledge and inference mechanisms according to the information provided by experts to determine the most appropriate decision [50]. AI uses different approaches, as shown in Figure 4 which is briefly described below. It should be noted that there are more techniques and subdivisions of AI such as machine learning, data mining, expert systems, among others; however, Figure 4 shows a compact classification where only the techniques identified in the review are related documentary, in a way that there is a coherence between Figures 3 and 4 .

A well-known technique used in AI is fuzzy logic that generates models from fuzzy sets. The fuzzy set is defined by a function where value 1 is associated with the elements that belong to the set and 0 to those that do not belong. The intermediate values are associated with elements that partially belong to it (associated with uncertainty). Fuzzy systems are modeled from a group of rules that produce one or more output values [51]. In this way, neuro-fuzzy systems integrate neural networks with fuzzy logic to create adaptable systems capable of making decisions in environments of uncertainty [52].

Another useful AI tool is Artificial Neural Networks (ANN), that consists of computationally emulating a biological neural network, which are distributed, adaptive, generally nonlinear learning machines built from many different processing elements called neurons organized into layers: input layer, output layer, and hidden layers. Each neuron receives connections from other neurons or from itself since interconnectivity defines topology. The signals flowing in the connections are scaled using adjustable parameters called weights. Neurons add all these contributions and produce an output that is a nonlinear (static) function of the sum. The outputs of the neurons become outputs of the system or are sent to it or to other neurons [53].

Support Vector Machine (SVM) is a supervised learning method to solve linear classification problems; however, they are also used in regression problems (Support Regression Vector) [54]. This represents the knowledge learned through the most informative points, called "support vectors", used to perform classification and data regression.

Agent-Based Modeling (ABM) is made to model complex processes to produce representative group behavior from interactions between different agents in a predetermined environment. Each agent has its own motivations and behaviors. Each agent is capable of affecting their environment; thus, agents must have the autonomy to pursue its motivations and to adapt their behaviors according to their needs. To facilitate interaction between agents, a set of rules that they must obey are established [55]. 


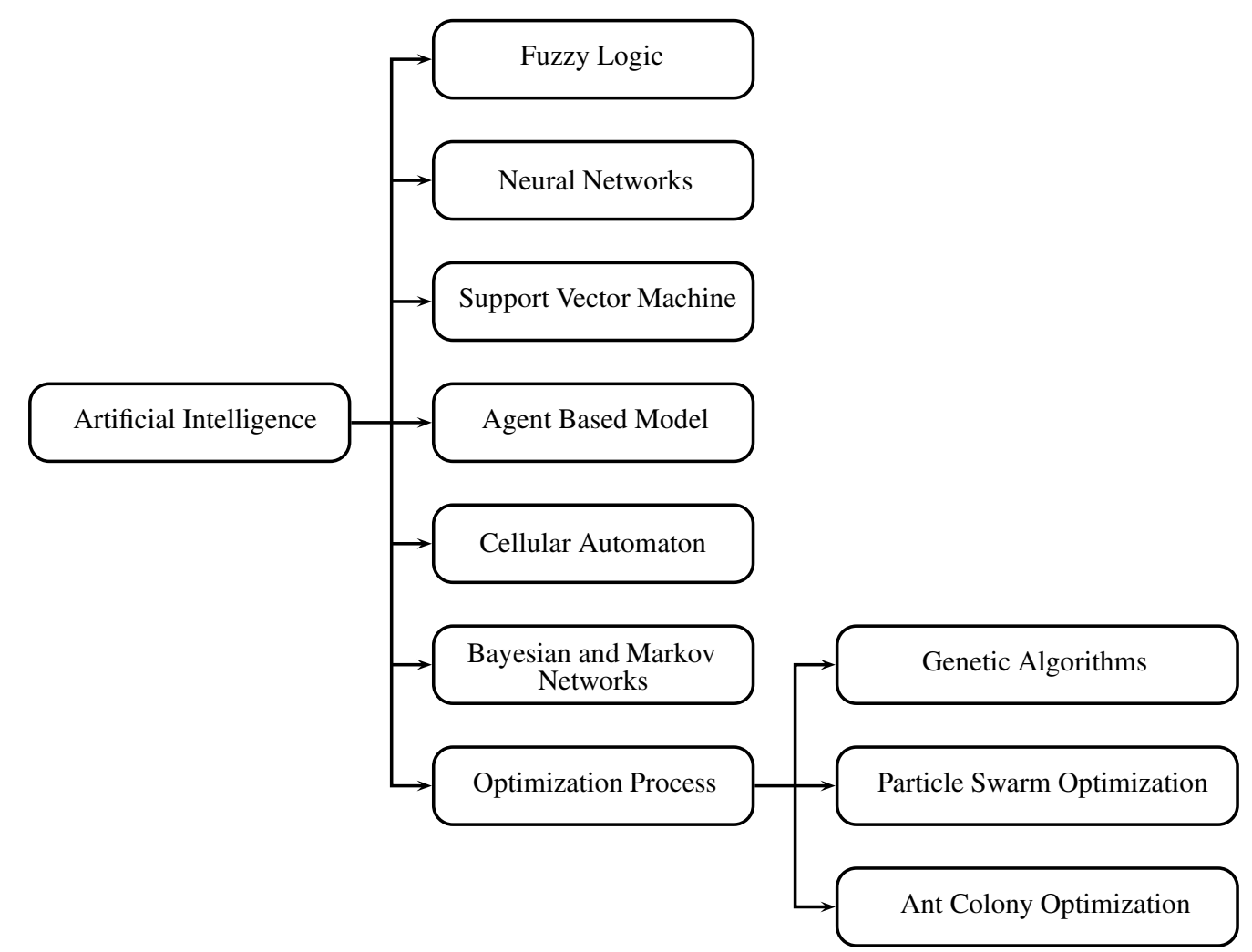

Figure 4. Artificial intelligence approaches according to a review of the applications on agricultural public policy.

Cellular Automaton (CA) consists of an infinite succession of finite state machines called cells. Each finite state machine is a state that changes simultaneously according to a local transition function, taking its current state and the states of its neighbors as inputs to the function. The system-wide configuration is defined in a global transition function from the set of all local transition functions [56].

Probabilistic computing allows to comprehend and compute with uncertainties inherent in natural data, which will enable building computers capable of understanding, predictions, and decision-making processes. In connection with methods based on statistics and probability, Bayesian Networks (BN) are probability-based artificial intelligence methods. These networks use a Directed Acyclic Graph (DAG), which is a graph with no cycles. The graph presents a joint probability distribution on the variables. The probabilities are presented in the arcs of the graph and the variables in the DAG nodes, which must be a finite number of mutually exclusive states. Bayesian networks are graphical modeling methods represented by a graph and a basic equation. The equation can be defined with a set of variables $V_{1}, V_{2}, V_{3}, \ldots, V_{n}$, where the joint probability is calculated from the product of all conditional probability tables [57,58]. AI is also used in Markov networks, which are similar to Bayesian networks; however, Markov networks are undirected and may be cyclic [59-61].

Artificial intelligence also uses metaheuristic optimization algorithms to search potential solutions, with Evolutionary Algorithms (EA) being one of the most used, which is described below as the most representative.

Genetic Algorithms (GA) are inspired by the process of natural selection, where the strongest individuals are those that survive; hence, the potential solution to a problem is an individual that can be represented by a set of parameters considered as the genes of a chromosome and are structured by a chain of values. A positive value, generally known as the fitness value, is used to reflect the degree of "goodness" of the chromosome to solve the problem [62]. The process consists of generating a set of individuals that are the candidates to solving the problem; then, the most promising individuals are selected and new individuals are generated to form the new population using crossover and mutation 
operators [63]. Therefore, as genetic evolution occurs, chromosomes tend to produce better-quality offspring, which means a better solution to the problem [62].

Particle Swarm Optimization (PSO) is based on the social behavior of a group of individuals, for example, swarms of insects, birds, or schools of fish. The behavior of the individuals are based on fundamental rules of interaction. The particle swarm optimization algorithm uses the population of individuals (swarm) to explore the search space. Each particle moves with adaptive speed within the search space, according to values associated with the best position of each particle and the best position of all particles; in this order, the best position obtained by the swarm is communicated to all particles [64].

Ant Colony Optimization (ACO) is a meta-heuristic and evolutionary approach algorithm in which several generations of artificial ants cooperatively seek the best solutions. First, the artificial ants move at random and deposit traces of chemical substances, called pheromones, along the paths they walk. Ants collect and store information from traces of pheromones found while moving. These traces of pheromones motivate them to follow the path with a large number of pheromones. As time progresses, the traces of pheromones are strengthened or diluted by the movement of the ants. At the end, all the ants chose the most optimal path that will be the best solution [65].

\section{Public Agricultural Policy}

As mentioned by Machado and Cardozo in [66,67], the agricultural policies in the world can be classified into five groups. The first corresponds to countries that do not have an agricultural policy in which macroeconomic policy prevails upon sectoral policies. The second group is the countries that have long-term policies, where their main characteristic is protectionism and aid for the sector. The third group consists of countries that have agriculture-oriented laws. The fourth group is made up of countries with directing laws for agriculture, which do not regulate specific aspects but give way to do this. The fifth group are countries where attempts are made to apply short-term agricultural policies, seeking an active policy that has great contradictions with macroeconomic policies, in which it has not been possible to generate long-term state policies [66,67].

In addition to recognizing that different types of agricultural policies may exist, it is necessary to clarify that agricultural policies must have common characteristics, so that they promote the development of society; these are listed below. The agricultural policies generated must affect both the short-term behavior of farmers and agricultural markets, and the structural factors that determine long-term behavior [68]. In the process of formulating agricultural public policies, it is necessary to take into account elements such as availability of labor, generation of employment, wages, conditions of employment, payments of farmers, types of producers (small and large), financing sources, land tenure, technology, inputs, production aid, demand, sale price, access to international markets, increased competitiveness, exports, and principles of sustainable development [69-74]. Under this perspective, agricultural policy encompasses market policies, such as structural policies. Therefore, an optimal agricultural policy would be one that helps both economic growth and the reduction of inequalities among members of society [68].

Also, agricultural public policies have two great challenges in the 21st century: food security and reduction of negative environmental impact [19,73,75-77]. Summing up, Agrarian policies must generate market and structural policies in the sector, seeking economic growth, reduction of inequalities, food security, and reduction of negative environmental impact; it is also necessary to take into account the climatic variability that affects agricultural production and promotes, when it occurs in extreme climatic conditions, the increase in hunger and malnutrition, where this situation is accentuated in countries located in the tropical zone. 
For the process of formulating agricultural policies, several authors recognize two possible routes. The first is called "from the top down", which starts from the vision of the leaders and decision makers in public policy, which does not correspond to the interests and realities of the agrarian sector. The second way is the called "bottom-up", starting from the territory and its regional particularities and needs [78]. The United Nations Development Program (UNDP) establishes necessary active participation in the public policy formulation process of the people who are involved in the economic, social, cultural, and political processes of the region; this means that the UNDP recommends the path from bottom-up [79].

In summary, the process of formulating an agrarian policy must be based on the development process called "bottom-up", starting from the economic, regional, cultural, and political needs of the territory [78], where the participation of all stakeholders in these areas must be active, having permanent access to decision making and power. This perspective is in accordance with the deliberative democracy model developed by J. Habermas.

\section{Artificial Intelligence Applied in Agricultural Public Policy}

Among the investigations that have used $\mathrm{AI}$ is that of Batarseh; it presents how data science can help the formulation of public policies in the agricultural sector in the United States [36]. Expert systems have been applied to determine the use of water and land in agriculture, agricultural production, the impact of climate, and public policy in the agricultural sector. In [80] is shown the importance of maps in the agricultural sector; in this application, noise is cleaned from maps, and replacing the noise with right data, this data can be used by different knowledge-based systems in decision and policy making in different sectors. Meanwhile in the research carried out by Mangalampalli, a decision-making system for agricultural production was developed, taking data mining as a decision-making tool [81], this paper performs detailed research in the development of an architectural model for implementing a high-end agricultural information system. This information system uses the latest technologies, intelligent systems, data-mining, data warehousing, and high-performance computer (HPC) grids.

Under the theory of the limited rationality model, public policy makers have different limitations for the construction of public policies, especially those that require a high level of complexity due to the large number of variables that they present, this statement is confirmed by various investigations such as $[82,83]$.

For this reason, some research has been carried out using AI to improve the decision-making process and to help public policy makers. For example, in El Salvador, different artificial intelligence techniques such as expert systems, case-based reasoning, artificial neural networks, and genetic algorithms have been implemented to make important public decisions [84]. In public health, models based on AI for the analysis of food quality and to thus develop public policies contribute to fighting obesity and diabetes [85]. Lastly, the research carried out in Europe [86] developed a model based on a multiple output neural network, which analyzed the complexity of the variables associated with innovation processes that will help decision making of public policies intended to support innovation.

Figure 3 presents a heat map identifying the variables of agriculture public policy versus AI techniques that were used in the investigations found and analyzed. In total, 89 applications were identified addressing various artificial intelligence techniques applied in public policy. Observing Figure 3, it is determined that the AI techniques mostly used are agent-based models, cellular automata, and evolutionary algorithms (especially genetic algorithms) and agrarian public policy variables most widely analyzed have been land use, agricultural production, and water use.

The following subsections describe how the different AI techniques have been applied in the public policy formulation process. 


\subsection{Fuzzy Logic}

Fuzzy logic is used to determine water use in agriculture, as mentioned in [87]. Also, Reference [88] shows an application of fuzzy logic to determine the impacts of a policy model for water reservoir management on agricultural production in India. Few investigations using fuzzy logic have been found, but those have been especially applied to determine the use of water resources in agricultural production.

The research [89] develops a fuzzy logic cognitive map to determine the perspective of different stakeholders on water quality in agriculture in rural farming communities in two districts of the dry zone of Sri Lanka. The research determined that management of surface and groundwater should be a shared responsibility between the government and the community of the region. The research [90] used the Water Resources Policy Support System (WRPSS) based on fuzzy logic, which analyzes management of water resources and environmental policy. This system was used in the semiarid region of northern Iran in the Caspian basin. Research results indicated that water consumption for agriculture in the Caspian basin is the most important criterion in the policy-making process and the least important is the dam infrastructure. Lastly, Reference [91] developed a mathematical model for estimating and predicting the economic security of the Ukrainian agricultural sector in the Vinnytsia region, based on fuzzy logic. The model carried out the projection until the year 2022.

\subsection{Artificial Neural Networks}

Artificial neural networks have been especially used to determine land use and agricultural production as in the Arasteh investigations [92]. Another example of the use of this technique is an investigation in Malaysia where a land use and coverage map was developed in the "Krau" Wildlife Reserve; here, the machine learning technique was also used [93]. In Lebanon, ANN was used to determine the status of the wheat harvest [94] and to determine the use of water as in the case of [87]. It has been applied to determine energy use as in the research by [95], which determined the future demand for electrical energy in agricultural areas in South Africa and in food security applications such as the research by [96]. It can be affirmed that ANN has been used to determine the production conditions of a certain agricultural product.

Another important application is the monitoring of heavy metals in aquatic environments; in this regard, in [97], the physicochemical indices of surface water and the concentrations of heavy metals in a drinking water source in the region of Lake Taihu, China were measured including water temperature, $\mathrm{pH}$, suspended matter, turbidity, and total nitrogen. Nitrate nitrogen, ammonia nitrogen, total phosphorus, orthophosphate, and permanganate index were used to simulate concentrations of total, particulate, and dissolved heavy metals using an artificial neural network and vector machine models. Sensitivity analysis showed that simulated heavy metal concentrations were more sensitive to $\mathrm{pH}$.

\subsection{Support Vector Machine}

This technique has been used for different applications. For example, in Pakistan, it was used to efficiently determine maize production in the Faisalabad region [98]. In Asia, Support Vector Regression (SVR) was used to predict the number of inputs necessary for the production of rice that ensures the food needs of the region [99] and to determine land use in agriculture [93] using support vector machine and artificial neural network classification techniques. In summary, SVM is a very useful tool to optimize the agricultural production processes of some types of crops in a given region.

The study of [100] developed a multi-stage land classification scheme based on decision trees, neural networks, and support vector machines for land with citrus crops, which automatically updates a Geographic Information System (GIS) in the province of Valencia in Spain. This allows policy makers to generate appropriate policies to improve citrus production. In the research by [101], a land use mapping system was developed in the agricultural sector using tools such as machine learning, cloud 
computing, and the Google Earth engine. The research analyzed 3 machine learning algorithms, namely Support Vector Machine with Radial Basis Function (SVM-RBF), Random Forest (RF), and Classification and Regression Tree (CART). These found that the SVM-RBF algorithm performed much better than RF and CART. Finally, the research in [102] developed a cereal production forecast system in China using vector support machines based on particle swarm optimization (PSO-SVM). This system is important since it means a relevant resource for formulating agricultural policies. The study determined PSO-SVM is an adequate method in the forecast of grain production.

In the study carried out in [103], supervised and unsupervised machine learning techniques were used to predict agricultural trade patterns in 7 products (wheat, corn, rice, sugar, beef, milk powder, and soy). The study found that these techniques are very useful for predicting trading patterns over traditional methods. It was also found that supervised machine learning techniques quantify well the economic factors underlying agricultural trade flows, although unsupervised approaches provide better long-term adjustments.

An important aspect in agriculture consists of the management of water resources, for which the precise estimation of the reference Evapotranspiration $\left(\mathrm{ET}_{0}\right)$ is required. However, due to insufficient meteorological data and the combination of undefined input, there may be uncertainties in simplified AI models. To abort this problem, [104] tested 29 combined scenarios of maximum and minimum temperature, wind speed, relative humidity, solar radiation, duration of insolation, and atmospheric pressure, through the application of artificial neural network, support vector regression, and extreme learning machine for arid Altay prefecture in China. In this work, the results confirmed the indispensable role of temperature and the predominant role of aerodynamics in the evapotranspiration process. Additionally, in [105], the future variability of $\mathrm{ET}_{0}$ is studied using extreme learning machine and support vector regression using data taken in a mountainous inland watershed in northwest China. According to the analyzes, it is observed that the variation of $\mathrm{ET}_{0}$ occurs mainly in the spring and autumn seasons, while the changes of $\mathrm{ET}_{0}$ in summer and winter are moderately small. Thus, it is observed that reducing the variation in monthly $\mathrm{ET}_{0}$ with $\mathrm{AI}$ is useful in practice for water, agriculture, and food management policies.

\subsection{Agent-Based Model}

According to this review, the artificial intelligence technique most used in processes of formulation of agricultural public policies is the agent-based model; it is applied to determine the use of land, water, machinery, agricultural production, fire prevention, climate in agriculture, government subsidies to the agricultural sector, ecological agriculture, sustainable agriculture, and agricultural policies. Among the investigations that have used the agent-based model applied to agrarian public policy are one carried out between the Netherlands and the United Kingdom, which simulated the impacts of possible policies on an agricultural community in Rafsanjan-Iran that faces water shortages; artificial neural network techniques and fuzzy logic were also used in this research [87]. Another research conducted in the United States modeled the decision-making process of farmers and the influence that policies could have on the adoption of best management practices [106]. An investigation carried out among researchers from Australia and China determined the possible effects of a new policy that consisted of leasing agricultural land and building larger farms [107]. Another study carried out in the Netherlands evaluated the possible consequences of land management policies and interventions to quantify their impacts on land adaptation and mitigation objectives [108]. Researchers from Peru, Spain, and the United Kingdom identified changes in flows of ecosystem services in response to changes in land use and climate and predicted the impact and scope of future land use scenarios in the Pucallpa-Peru region and the food supply needs of local communities [109]. A study in China analyzed the behaviors and decision-making processes of farmers and other agents [110]. Another study analyzed dynamic interactions between changing water demands, based on limited water resources in the arid western United States, taking into account population growth, land use conversion, and scenarios of climate change [111]. In the United Kingdom, it was used for the effect of increasing government incentives 
to improve biodiversity and its influence on the decision-making process on land managers [112]. In Brazil, fire risk maps were made for production in agricultural areas [113]. Another study in the UK explored various mechanisms to give incentives to farmers and to thus improve biodiversity management, including activity-based and results-based incentives, in which farmers potentially benefit from the activities of neighbors [114]. Also, the United Kingdom investigated how undetected sinks can influence the persistence and richness of species in different political and socioeconomic contexts [115] and analyzed large-scale biodiversity policies, in which independent land managers, subjected to financial constraints, make decisions subject to a range of objectives [116]. Germany simulated how farmers interact with each other and react to changes in their economic and natural environment [117]. In France, they investigated the prevention of forest fires and the abandonment of farmland [118]. Finally, a study carried out in Australia developed a simulation model to analyze the long-term viability of an agricultural region with scenarios of change in land use, perception and management of salinity risk, future climate change, introduction and adoption of new technologies, changes in policies, markets, social networks, evolution of the social value, and functions of the municipality [119]. In summary, agent-based models are very useful for predicting the possible future behaviors of an agricultural community, after the implementation of various agricultural public policies in a given region.

\subsection{Cellular Automaton}

Another AI technique widely used is the cellular automata; this was specially applied to determine the use of land, as in the research of Arasteh in Iran, consisting of projecting the trajectories of urban growth and its influence on agriculture. Besides, this research applied artificial neural networks [92]. Other research sought to determine changes in land use due to the expansion of agriculture, environmental calamities, and government policies on the Upper Narmada-India basin [120]. Researchers simulated the conflict between the protection of agricultural land and urban growth in China and the ability to ensure food security in the region. This research also used artificial neural networks [96]. Cellular automaton was also used to forecast land cover in the Allahabad-India district [121], using it to determine land use change and future growth in Dehradun [122]. In Germany, this was employed to simulate alternative scenarios in land use, evaluating the environmental impact [123]. In the Netherlands, the aim was to determine the possible impacts of different public policy alternatives, determining through simulation the gains in the agricultural sector, the forestry area, the use and availability of water, land degradation, and changes in the use of the soil [124]. Lastly, there is also a noteworthy study where cellular automaton was used to simulate scenarios in the change of land use and its sustainable use in Jiaxing of Zhejiang province in China [125]. In conclusion, a cellular automaton is a useful tool to predict future scenarios related to variables directly associated with agricultural production such as land use, water, food production, sustainable agriculture, and environmental impacts.

\subsection{Bayesian and Markov Networks}

Bayesian networks have been applied to determine water use and the development of sustainable agriculture, as presented in the research by [126], carried out in the Apulia region of southern Italy. In the San Joaquin Valley in California, United States, a study was carried out to generate an optimal management policy for pest management in cotton crops, which balances the loss of yield and the cost of pesticide applications [127]. This application employs a Markov decision process model. Data science has been used to predict extreme weather conditions that can lead to drought or flooding in agricultural crops [128]. In this study, a data-mining algorithm making use of the concepts of minimal occurrences with constraints and time lags is used to discover association rules between extreme rainfall events and climatic indices. This investigation uses an algorithm based on counting what are known as minimal occurrences of episodes. A minimal occurrence of an episode is defined 
as a window (or contiguous slice) of the input sequence in which the episode occurs, subject to the condition that no proper subwindow of this window contains an occurrence of the episode.

The research [129] developed an annual probabilistic model based on Bayesian networks for a hydro-economic system of groundwater quality control. The model was applied in the "El Salobral-Los Llanos" aquifer unit within the aquifer system of the eastern Mancha in Spain. The importance of this lies in the fact that the crops of the region depend significantly on this system. The Bayesian networks model proved to be a suitable support system for the decision-making process in public policy. The study of [130] uses artificial intelligence tools such as Bayesian and Markov networks to develop decision models as strategies for managing diseases and weeds in crops. The study develops models that help promote sustainable agriculture. Finally, the research in [131] proposed a methodology to create a model based on Bayesian networks to evaluate agricultural development projects in Africa. The model is a support system for decision making on the viability of agricultural projects that predict the present value and the return on investment in different risk scenarios.

\subsection{Evolutionary Algorithms}

These sets of optimization algorithms are used to determine agricultural production, as in Ali's research in which a genetic algorithm was used to predict the efficiency of agricultural production in Pakistan taking into account the climate [132]. Besides, the research carried out in China was used to measure the Leaf Area Index (LAI) and the Leaf Chlorophyll Content (LCC), two important variables for crop growth [133]. Also in China, the investigations aimed to optimize crop production [134,135]. It has also been applied for the efficient use of water in agriculture, for example, a research carried out in the United States which sought to determine the optimal allocation of available water resources [136]. Also in the United States, other research sought to determine the optimal use of water resources in agriculture in times of drought [137]. Researchers from China, working together with Australia, simulated scenarios for sustainable land use, taking into account variables such as water use and reduction of negative environmental impact [125]. Lastly, research was also carried out in China to optimize land use, balancing it with the reduction of the negative environmental impact, reducing erosion and thus seeking sustainable agriculture [138]. In summary, evolutionary algorithms especially genetic algorithms are AI tools to optimize efficiency in agricultural production, either by improving the use of associated resources, reducing the negative impact in the environment, or seeking to achieve sustainable agriculture.

\section{Discussion}

When analyzing the use of AI tools applied in the process of formulating agricultural public policies, it is stated that they have been very useful and that their applications are related in three main aspects. The first refers to forecasting the future tendency of some farming communities regarding the possible implementation of an agrarian public policy. The AI employing this forecast is the agent-based model. The second application is to obtain useful information that helps agricultural public policy makers make better decisions, which shows that the preferred tools for this function are those related to artificial neural networks and support vector machine. The third application determines different forms of agricultural production, taking into account anagement of resources such as land and water and evaluating the results of this production as units produced and the environmental impacts. The tools employed were cellular automata, fuzzy logic, and Bayesian networks. It is noticeable that genetic algorithms, artificial neural networks, and support vector machine have been very useful in optimizing production processes. This review shows that the application of artificial intelligence tools for decision making on different variables within the agrarian sector is important given its usefulness for public policy makers. 
This review is intended to serve as a reference to later be able to generate a model that facilitates the process of formulating agricultural policies in accordance with the needs of a certain region. With the formulation of an adequate model of agrarian public policies, it would be expected to achieve economic growth, reduction of inequalities, food security, and reduction of the negative environmental impact of the region where it is applied.

This review allows to have a context on the different aspects to be considered since it is very important that agricultural policies do not bring undesired and not very beneficial consequences for the community; this is due to the complexity of agrarian systems accompanied by the limited rationality of human beings when making decisions (mainly by the rulers). An example of unexpected effects may be that, despite increasing production, environmental damage may occur.

Many researchers have identified different problems associated with the high degree of complexity that public policy formulation presents. The first problem is that the public policy formulation process has a complex environment, which makes it vulnerable to political resistance [139], which deals with short-term policies that bring clear benefits but, in the long term, bring unwanted consequences against the stated objectives [139]. For this reason, systems that manage to predict these long-term consequences will be very useful. This proposition has been presented in different investigations such as [87,106-119] where agent-based models were used; likewise, the research of [92,96,120-125] employed the technique of cellular automaton.

Another associated problem is the cost of experimentation, which is very high, as established in [140], where the experimentation process is necessary when the public policy problem is very complex. Therefore, the experimentation allows policy makers to observe the behaviors generated and to make the respective adjustments. However, the issue lies on the implemented policies that do not comply such adjustments and their consequences are irreversible; for this reason, tools that allow simulating and predicting these behaviors become suitable as are artificial intelligence systems [141].

There are three other associated problems that are more political in nature. The first is the need to reach an agreement among the stakeholders that intervene during the policy formulation process [142]; therefore, solutions can be sought from different simulated scenarios in which a consensus is reached between the parties. The second problem is the excessive confidence of those responsible for formulating public policies, with a high percentage of subjectivity, because they believe more in their own decision-making capacities than in the advice of expert systems [143]. The third is the tendency for decision makers to attribute undesirable events to external sources instead of assuming their responsibilities, for example, blaming opposition parties or international enmities for unwanted events [144]. Even though these problems are more of a humanistic and subjective nature, the way to integrate AI tools to mitigate these problems associated with public policy formulation processes is of high relevance.

Considering the above for future developments, hybrid techniques could be used for the approach to the decision-making system according to this review. In the same way, a comparison between techniques might establish the most suitable one. In this regard, it is important to unify performance metrics as well as the conditions on which the application of AI techniques are carried out.

Additionally, for the approach of the models, aspects such as economic, environmental, and technological, among others, must be considered in the objective functions (performance or adjustment).

\section{Conclusions}

Artificial intelligence tools are very useful in the decision-making process, reducing the level of uncertainty given by the limited rationality of the human being, which can be seen in the identified public policy applications.

Agricultural policies must generate both market and structural policies, seeking economic growth, reduction of inequalities, food security, and reduction of negative environmental impact. The development of AI promotes positive impacts in local and regional farming communities given 
the constant innovation of technology and technological resources, which is also an influential factor in local economies.

The best way for the process of formulating an agrarian policy is call "bottom-up", based on the economic, regional, cultural, and political needs of the territory, where it is also necessary to ensure the participation of all stakeholders during the process.

According to this review, the artificial intelligence technique most used in the processes of formulation of agricultural public policies is agent-based model, specially utilized to determine the use of land and to evaluate policy alternatives taking into account climate change, negative environmental impact, and government subsidies. The second AI technique most widely utilized is the cellular automata, mainly used to project future scenarios of land use under different circumstances such as economic and technological one, among others. Genetic algorithms is the third most utilized technique to optimize agricultural production processes like increasing production, improving the use of inputs, managing water resources, and reducing the negative environmental impact.

Artificial intelligence tools have been mainly used in 3 different applications. The first is to forecast future behaviors in agricultural communities with the possibility of implementing an agricultural policy, where agent-based model is used as the main tool. The second is to extract useful information for the formulation process, where artificial neural networks and support vector machine are the tools most employed. Finally, the application most widely used is to improve agricultural production processes in which different AI tools are applied, given the relevance of the rational use of water.

In summary, the great usefulness of AI tools is evident in the process of formulating agricultural public policies, which serves to plan possible results and impacts that the implementation of such policies may have. Therefore, the AI tools and the results obtained become great instruments to obtain suitable information for public policy makers and to thus seek policies that improve the quality of life of people belonging to the agricultural sector and to the entire population of a country, based on the importance of this sector.

Author Contributions: Conceptualization, J.M.S., J.P.R., and H.E.E.; methodology, J.M.S. and H.E.E.; project administration, J.P.R.; supervision, J.P.R.; validation, J.M.S.; writing—original draft, J.M.S.; writing-review and editing, J.M.S., J.P.R., and H.E.E. All authors have read and agreed to the published version of the manuscript.

Funding: This research received no external funding.

Acknowledgments: The authors express gratitude to the Universidad Distrital Francisco José de Caldas.

Conflicts of Interest: The authors declare no conflict of interest.

\section{References}

1. Mejía Jímenez, J. Modelos de implementación de las políticas públicas en Colombia y su impacto en el bienestar social. Analecta Política 2011, 2, 141-164.

2. Simon, H. Rational Decision Making in Business Organizations. Am. Econ. Rev. 1979, 69, 493-513.

3. Martinez, A. Las Políticas Públicas Modelos y Contenido. Fermentum 2015, 25, 34-40.

4. Cohen, M.D.; March, J.G.; Olsen, J.P. A Garbage Can Model of Organizational Choice. Adm. Sci. Q. 1972, 17, 1-25. [CrossRef]

5. Cuchumbé Holguín, N.; Alexander, G.J. Aproximación a la democracia deliberativa de Habermas. Discusiones Filosóficas 2013, 14, 141-159.

6. Chávez, E.; Arguello, A.; Viscarra, C.; Aro, G.; Albarrasín, M. Inteligencia Artificial en la toma de decisiones gerenciales. Rev. Dilemas Contemp. Educ. Política y Valores 2018, 6, 1-12.

7. Flath, C.; Stein, N. Towards a data science toolbox for industrial analytics applications. Comput. Ind. 2018, 94, 16-25. [CrossRef]

8. Lin, H.; Zhu, H.; Zuo, Y.; Zhu, C.; Wu, J.; Xiong, H. Collaborative company profiling: Insights from an employee's perspective. In Proceedings of the 31st AAAI Conference on Artificial Intelligence, AAAI 2017, San Francisco, CA, USA, 4-9 February 2017; pp. 1417-1423.

9. Cisneros, A. Sistema De Inteligencia Artificial Como Soporte A La Toma De Decisiones Financieras En Las Sociedades De Corretaje. Rev. Centro Investig. Cienc. Adm. Gerenciales 2013, 4, 54-73. 
10. Fernández, J.; Martín, Q.; Corchado Rodríguez, J. Business Intelligence Expert System on SOX Compliance over the Purchase Orders Creation Process. Intell. Inf. Manag. 2013, 5, 49-72. [CrossRef]

11. Peña, J.; Chan, A.; Balam, C. Sistema Experto En Apoyo A Toma De Decisiones Para Aprobación De Líneas De Crédito. Pistas Educ. 2017, 39, 402-411.

12. López, A.; Silega, N. Ontología para la clasificación del riesgo de crédito en el Banco Nacional de Cuba Ontology to credit risk classification in the National Bank of Cuba. Serie Científica Univ. Cienc. Inform. 2015, 8, 17-31.

13. Sosa, M. Inteligencia artificial en la gestión financiera empresarial. Pensam. Gestión 2007, 23, $153-186$.

14. Larrañaga, J.; Zulueta, E.; Elizagarate, F.; Bernardo, J. Algoritmos Meméticos En Problemas De Investigación Operativa. Rev. Dir. Adm. Empres. 2011, 18, 189-208.

15. Torres, S.; Lugo, J.; Pinero, P.Y.; Torres, K.; Perdomo, A.; Cuza, B.; Cuza, A.; Miroslava, L. Técnicas formales y de inteligencia artificial para la gestión de recursos humanos en proyectos informáticos. Rev. Cuba. Cienc. Inform. 2014, 8, 41-52.

16. Menon, V.; Rahulnath, H. A novel approach to evaluate and rank candidates in a recruitment process by estimating emotional intelligence through social media data. In Proceedings of the 2016 International Conference on Next Generation Intelligent Systems, ICNGIS 2016, Kottayam, India, 1-3 September 2017. [CrossRef]

17. Nawaz, N. Artificial intelligence interchange human intervention in the recruitment process in Indian software industry. Int. J. Adv. Trends Comput. Sci. Eng. 2019, 8, 1433-1442. [CrossRef]

18. Van Esch, P.; Black, J.; Ferolie, J. Marketing AI recruitment: The next phase in job application and selection. Comput. Hum. Behav. 2019, 90, 215-222. [CrossRef]

19. Abarca, F.; Campos, F.; Reinoso, R. Methodology of Decision Support through GIS and Artificial Intelligence: Implementation for Demographic Characterization of Andalusia based on Dwelling. Estoa 2017, 6, 33-51. [CrossRef]

20. Hernández, E.; Duque, N.; Moreno, J. Generación de pronósticos para la precipitación diaria en una serie de tiempo de datos meteorológicos. Ingenio Magno 2016, 7, 144-155.

21. Santacreu, L.J.; Talavera, A.; Aguasca, R.; Galván, B.J. Sistema experto para tomar decisiones de emergencias y seguridad ante meteorología adversa. Dyna Ing. E Ind. 2015, 90, 502-512.

22. Moon, S.; Kim, Y.; Lee, Y.; Moon, B. Application of machine learning to an early warning system for very short-term heavy rainfall. J. Hydrol. 2019, 568, 1042-1054. [CrossRef]

23. Moreno, J.; Sanchez, J.; Espitia, H. Water Level Prediction Using Artificial Neural Network Model. Int. J. Appl. Eng. Res. 2018, 13, 14378-14381.

24. David, $\breve{S}$. Forecasting of Convective Precipitation Through NWP Models and Algorithm of Storms Prediction. In Advances in Intelligent Systems and Computing; Springer: Cham, Switzerland, 2017; Volume 573. [CrossRef]

25. Ochoa, A.; Orellana, A.; Sánchez, Y.; Dávila, F. Componente web para el análisis de información clínica usando la técnica de Minería de Datos por agrupamiento Web component for the analysis of clinical information using the technique of clustering data mining. Rev. Cuba. Inform. Medica 2014, 6, 5-16.

26. Chen, M.; Hao, Y.; Hwang, K.; Wang, L.; Wang, L. Disease Prediction by Machine Learning over Big Data from Healthcare Communities. IEEE Access 2017, 5, 8869-8879. [CrossRef]

27. Chen, P.; Lin, C.; Wu, W. Big data management in healthcare: Adoption challenges and implications. Int. J. Inf. Manag. 2020, 53, 102078. [CrossRef]

28. Jiang, F.; Jiang, Y.; Zhi, H.; Dong, Y.; Li, H.; Ma, S.; Wang, Y.; Dong, Q.; Shen, H.; Wang, Y. Artificial intelligence in healthcare: Past, present and future. Stroke Vasc. Neurol. 2017, 2, 230-243. [CrossRef]

29. Mehta, N.; Pandit, A. Concurrence of big data analytics and healthcare: A systematic review. Int. J. Med. Inform. 2018, 114, 57-65. [CrossRef]

30. Ramesh, D.; Suraj, P.; Saini, L. Big data analytics in healthcare: A survey approach. In Proceedings of the International Conference on Microelectronics, Computing and Communication, MicroCom 2016, Durgapur, India, 23-25 January 2016. [CrossRef]

31. Thesmar, D.; Sraer, D.; Pinheiro, L.; Dadson, N.; Veliche, R.; Greenberg, P. Combining the Power of Artificial Intelligence with the Richness of Healthcare Claims Data: Opportunities and Challenges. PharmacoEconomics 2019, 37, 745-752. [CrossRef]

32. Badaracco, N.; Mariño, S.; Alfonzo, P. Modelización De La Asignación De Aulas Con Técnicas Simbólicas De La Ia Como Ayuda A La Toma De Decisiones. Rev. Electron. Estud. Telemat. 2014, 13, 16-35. 
33. Acosta Ramírez, R.; Verdecia Díaz, Y.; Amoroso Fernández, Y. Jurimetría: Una opción para la sociedad. Serie Científica de la Universidad de las Ciencias Informáticas 2016, 9, 1-6.

34. Feras, B.; Ruixin, Y. Data Democracy: At the Nexus of Artificial Intelligence, Software Development, and Knowledge Engineering, 1st ed.; Academic Press Inc.: London, UK, 2020; p. 266.

35. Lukas, F.; Lucia, P. Quantitative Modelling in Economics with Advanced Artificial Neural Networks. Procedia Econ. Financ. 2015, 34, 194-201. [CrossRef]

36. Batarseh, F.; Yang, R. Federal Data Science: Transforming Government and Agricultural Policy Using Artificial Intelligence, 1st ed.; Academic Press: London, UK, 2017; p. 256.

37. Feng, L.; Zhang, J. Application of artificial neural networks in tendency forecasting of economic growth. Econ. Model. 2014, 40, 76-80. [CrossRef]

38. Exterkate, P.; Groenen, P.; Heij, C.; van Dijk, D. Nonlinear forecasting with many predictors using kernel ridge regression. Int. J. Forecast. 2016, 32, 736-753. [CrossRef]

39. Porrini, D.; Fusco, G.; Magazzino, C. Black boxes and market efficiency: The effect on premiums in the Italian motor-vehicle insurance market. Eur. J. Law Econ. 2020, 49, 455-472. [CrossRef]

40. Tubaro, P.; Casilli, A. Micro-work, artificial intelligence and the automotive industry. J. Ind. Bus. Econ. 2019, 46, 333-345. [CrossRef]

41. Fatima, S.; Desouza, K.; Dawson, G. National strategic artificial intelligence plans: A multi-dimensional analysis. Econ. Anal. Policy 2020, 67, 178-194. [CrossRef]

42. Arenal, A.; Na, C.A.; Feijoo, C.; Ramos, S.; Moreno, A. Innovation ecosystems theory revisited: The case of artificial intelligence in China. Telecommun. Policy 2020, 44, 1-27. [CrossRef]

43. Tamayo, M. El Proceso de la Investigación Científica, 5th ed.; Limusa: Mexico City, Mexico, 2011; p. 444.

44. Creswell, J. Researh Design, Qualitative, Quantitative, and Mixed Methods Approachs, 4th ed.; SAGE: Los Angeles, CA, USA; London, UK; New Delhi, India; Singapore; Washington, DC, USA, 2014; p. 43.

45. Liberati, A.; Altman, D.; Tetzlaff, J.; Mulrow, C.; Gøtzsche, P.; Ioannidis, J.; Clarke, M.; Devereaux, P.; Kleijnen, J.; Moher, D. The PRISMA Statement for Reporting Systematic Reviews and Meta-Analyses of Studies That Evaluate Health Care Interventions: Explanation and Elaboration. PLOS Med. 2009, 6, e1000100. [CrossRef]

46. Urrutia, G.; Bonfill, X. Declaración PRISMA: Una propuesta para mejorar la publicación de revisiones sistematicas y metaanálisis. Med. Clínica 2010, 135, 507-511. [CrossRef]

47. Morelock, J.R. A systematic literature review of engineering identity: Definitions, factors, and interventions affecting development, and means of measurement. Eur. J. Eng. Educ. 2017, 42, 1240-1262. [CrossRef]

48. Tursunbayeva, A.; Franco, M.; Pagliari, C. Use of social media for e-Government in the public health sector: A systematic review of published studies. Gov. Inf. Q. 2017, 34, 270-282. [CrossRef]

49. Manyika, J.; Chui, M.; Miremadi, M.; Bughin, J.; George, K.; Willmott, K.; Willmott, P.; Dewhurst, M. Un Futuro Que Funciona: Automatización, Empleo y Productividad; McKinsey Global Institute: New York, NY, USA, 2017; p. 27.

50. Chen, X.; Xv, J.; Ye, K.; Zhou, Y.; You, J.; Jin, K. A Brief Discussion on the Applications of Artificial Intelligence in the Field of Valuation. J. Phys. Conf. Ser. 2018, 1069. [CrossRef]

51. Jaiswal, R.; Sarode, M. An Overview on Fuzzy Logic and Fuzzy Elements. Int. Res. J. Comput. Sci. 2015, 3, 29-34.

52. Simiński, K. Rule weights in a neuro-fuzzy system with a hierarchical domain partition. Int. J. Appl. Math. Comput. Sci. 2010, 20, 337-347. [CrossRef]

53. Guresen, E.; Kayakutlu, G. Definition of Artificial Neural Networks with comparison to other networks. Procedia Comput. Sci. 2011, 3, 426-433. [CrossRef]

54. Velasquez, J.; Olaya, Y.; Franco, C. Predicción de series temporales usando máquinas de vectores de soporte. Ingeniare Rev. Chil. Ing. 2010, 18, 64-75. [CrossRef]

55. Dauby, J.; Upholzer, S. Exploring behavioral dynamics in systems of systems. Procedia Comput. Sci. 2011, 6, 34-39. [CrossRef]

56. Martin, B. Damage spreading and $\mu$-sensitivity on cellular automata. Ergod. Theory Dyn. Syst. 2007, 27, 545-565. [CrossRef]

57. Hossain, M.; Muromachi, Y. A Bayesian network based framework for real-time crash prediction on the basic freeway segments of urban expressways. Accid. Anal. Prev. 2012, 45, 373-381. [CrossRef]

58. Cozman, F. Independence for full conditional probabilities: Structure, factorization, non-uniqueness, and Bayesian networks. Int. J. Approx. Reason. 2013, 54, 1261-1278. [CrossRef] 
59. Ghahramani, Z. An introduction to hidden markov models and bayesian networks. Int. J. Pattern Recognit. Artif. Intell. 2001, 15, 9-42. [CrossRef]

60. Jamroga, W. A temporal logic for Markov chains. In Proceedings of the 7th International Joint Conference on Autonomous Agents and Multiagent Systems (AAMAS), Estoril, Portugal, 12-16 May 2008; Volume 2, pp. 697-704.

61. Amayri, M.; Ngo, Q.; EL-Safadi, E.; Ploix, S. Bayesian Network and Hidden Markov Model for Estimating occupancy from measurements and knowledge. In Proceedings of the 9th IEEE International Conference on Intelligent Data Acquisition and Advanced Computing Systems: Technology and Applications, Bucharest, Romania, 21-23 September 2017; Volume 2, pp. 697-704. [CrossRef]

62. Man, K.; Tang, K.; Kwong, S. Genetic algorithms: Concepts and applications. IEEE Trans. Ind. Electron. 1996, 43, 519-534. [CrossRef]

63. Inza, I.; Larrañaga, P.; Etxeberria, R.; Sierra, B. Feature Subset Selection by Bayesian network-based optimization. Artif. Intell. 2000, 123, 157-184. [CrossRef]

64. Pavlidis, N.; Parsopoulos, K.; Vrahatis, M. Computing Nash equilibria through computational intelligence methods. J. Comput. Appl. Math. 2005, 175, 113-136. [CrossRef]

65. Jang, S.; Roh, J.; Kim, W.; Sherpa, T.; Kim, J.; Park, J. A novel binary ant colony optimization: Application to the unit commitment problem of power systems. J. Electr. Eng. Technol. 2011, 6, 174-181. [CrossRef]

66. Machado, A. De la Estructura Agraria al Sistema Agroindustrial; Universidad Nacional De Colombia: Bogota, DC, USA, 2002; p. 320.

67. Cardozo, O. Incidencia de poderes exógenos en las políticas públicas y en el sector rural en Colombia. Apunt. CENES 2011, 30, 103-116.

68. Guanziroli, C. Evolución de la Política Agrícola Brasileña: 1980-2010. Mundo Agrário 2014, 15, 1-33.

69. Albornoz, M. Transformaciones en la política de tierras y redistribución agraria del Ecuador. Una visión desde las redes de política pública. Mundo Agrar. Rev. Estud. Rural 2016, 17, 23.

70. Craviotti, C. Agricultura familiar-Agronegocios: Disputas, interrelaciones y proyectos. Territorios 2014, 16, 17-38. [CrossRef]

71. Escalante, R.; Catalán, H.; Basurto, S. Determinantes del crédito en el sector agropecuario mexicano: Un análisis mediante un modelo Probit. Cuad. Desarro. Rural 2013, 10, 101-124.

72. Larrubia Vargas, R. La política agraria común y sus reformas: Reflexiones en torno a la reforma de 2014-2020. Cuadernos Geográfico 2017, 56, 124-147.

73. Ríos Núñez, S.; Torres Osses, G. El sector agropecuario en la región de Los Lagos y el paradigma “Chile potencia alimentaria": Desafíos para la política agraria nacional. Mundo Agrario 2014, 15, 1-15.

74. Rodrí́guez Sperat, R. Representa el capital un limitante para la productividad en la Agricultura Familiar, Un estudio de caso en Santiago del Estero, Argentina. Rev. Venez. Econ. Soc. 2014, 14, 9-34.

75. Suárez, J. Producción integrada de alimentos y energiía a escala local en Cuba: Bases para un desarrollo sostenible. Pastos Forrajes 2015, 38, 3-10.

76. Temprano, A. Política agraria común y la de cohesión frente a la Estrategia Europa 2020. Probl. Desarro. 2013, 173, 105-132. [CrossRef]

77. Boza, S. Evolución del sector agrícola-ecológico: El caso de Andalucía , España *. Cuad. Desarro. Rural 2013, 10, 291-310.

78. Morgan, S.; Marsden, T.; Miele, M.; Morley, A. Agricultural multifunctionality and farmers' entrepreneurial skills: A study of Tuscan and Welsh farmers. J. Rural Stud. 2010, 26, 116-129. [CrossRef]

79. Rodríguez, E.; Martínez, G.; Mora, J. La Crisis Del Sector Agropecuario Colombiano: Cuál Es La Responsabilidad De Las Políticas Públicas. Tendencias 2015, XVI, 159-174. [CrossRef]

80. Aslam, M.; Abdullah, A. A Methodology and a Tool to Prepare Agro-Meteorological Maps as a Source of Big Data. In Proceedings of the 2015 IEEE International Conference on Multimedia Big Data, BigMM 2015, Beijing, China, 20-22 April 2015; pp. 208-211. [CrossRef]

81. Mangalampalli, A.; Shinde, C.; Chakravarthy, R. A high-end ICT-based information system architecture for effective analysis and usage of agricultural data in decision-making. CAB Rev. Perspect. Agric. Vet. Sci. Nutr. Nat. Resour. 2006, 1, 11. [CrossRef]

82. Shaffer, R. Cognitive load and issue engagement in congressional discourse. Cogn. Syst. Res. 2017, 44, 89-99. [CrossRef]

83. Thomas, H. Modeling contagion in policy systems. Cogn. Syst. Res. 2017, 44, 74-88. [CrossRef] 
84. Alfaro Parada, M. Utilización de metodologías de Inteligencia Artificial y sus aplicaciones en El Salvador. ING-NOVACIÓN 2012, 3, 57-68.

85. Bourguet, J.; Thomopoulos, R.; Mugnier, M.; Abécassis, J. An artificial intelligence-based approach to deal with argumentation applied to food quality in a public health policy. Expert Syst. Appl. 2013, 40, 4539-4546. [CrossRef]

86. Hajek, P.; Henriques, R. Modelling innovation performance of European regions using multi-output neural networks. PLoS ONE 2017, 12, e0189746. [CrossRef] [PubMed]

87. Mehryar, S.; Sliuzas, R.; Schwarz, N.; Sharifi, A.; Van Maarseveen, M. From individual Fuzzy Cognitive Maps to Agent Based Models: Modeling multi-factorial and multi-stakeholder decision-making for water scarcity. J. Environ. Manag. 2019, 250, 109482. [CrossRef] [PubMed]

88. Suresh, K.; Mujumdar, P. A fuzzy risk approach for performance evaluation of an irrigation reservoir system. Agric. Water Manag. 2004, 69, 159-177. [CrossRef]

89. Thoradeniya, B.; Pinto, U.; Maheshwari, B. Perspectives on impacts of water quality on agriculture and community well-being-a key informant study from Sri Lanka. Environ. Sci. Pollut. Res. 2019, 26, 2047-2061. [CrossRef]

90. Aghmashhadi, A.; Cirella, G.; Zahedi, S.; Kazemi, A. Water resource policy support system of the Caspian Basin. AIMS Environ. Sci. 2019, 6, 242-261. [CrossRef]

91. Nikolenko, L.; Jurakovskiy, E.; Ivanyuta, N.; Andronik, O.; Sharkovska, S. Investment policy of governance of economic security of agrarian sector of Ukraine on the basis of theory of fuzzy logics. Montenegrin J. Econ. 2018, 14, 125-140. [CrossRef]

92. Arasteh, R.; Ali Abbaspour, R.; Salmanmahiny, A. A modeling approach to path dependent and non-path dependent urban allocation in a rapidly growing region. Sustain. Cities Soc. 2019, 44, 378-394. [CrossRef]

93. Nisa Shaharum, N.; Mohd Shafri, H.; Gambo, J.; Zainal Abidin, F. Mapping of Krau Wildlife Reserve (KWR) protected area using Landsat 8 and supervised classification algorithms. Remote Sens. Appl. Soc. Environ. 2018, 10, 24-35. [CrossRef]

94. Awad, M. New mathematical models to estimate wheat Leaf Chlorophyll Content based on Artificial Neural Network and remote sensing data. In Proceedings of the 2016 IEEE International Multidisciplinary Conference on Engineering Technology, IMCET 2016, Beirut, Lebanon, 2-4 November 2016; pp. 86-91. [CrossRef]

95. Tartibu, L. A predictive approach for effective management and planning within the energy sector of South Africa. In Proceedings of the International Conference on Industrial Engineering and Operations Management, Paris, France, 26-27 July 2018; Volume 2018, pp. 195-202.

96. Ma, S.; Wu, K.; Lao, C.; Zhong, Y.; Zhang, T.; Huang, T. Establishment and application of iZone system for intelligently identifying preserved zones of permanent prime farmland. Trans. Chin. Soc. Agric. Eng. 2017, 33, 276-282.

97. Lu, H.; Li, H.; Liu, T.; Fan, Y.; Yuan, Y.; Xie, M.; Qian, X. Simulating heavy metal concentrations in an aquatic environment using artificial intelligence models and physicochemical indexes. Sci. Total Environ. 2019, 694, 1-15. [CrossRef] [PubMed]

98. Ahmad, I.; Saeed, U.; Fahad, M.; Ullah, A.; Habib ur Rahman, M.; Ahmad, A.; Judge, J. Yield Forecasting of Spring Maize Using Remote Sensing and Crop Modeling in Faisalabad-Punjab Pakistan. J. Indian Soc. Remote Sens. 2018, 46, 1701-1711. [CrossRef]

99. Yousefi, M.; Khoshnevisan, B.; Shamshirband, S.; Motamedi, S.; Nasir, M.H.; Arif, M.; Ahmad, R. Support vector regression methodology for prediction of output energy in rice production. Stoch. Environ. Res. Risk Assess. 2015, 29, 2115-2126. [CrossRef]

100. Amorós López, J.; Izquierdo Verdiguier, E.; Gómez Chova, L.; Muñoz Marí, J.; Rodríguez Barreiro, J.; Camps Valls, G.; Calpe Maravilla, J. Land cover classification of VHR airborne images for citrus grove identification. ISPRS J. Photogramm. Remote Sens. 2011, 66, 115-123. [CrossRef]

101. Praveen, B.; Mustak, S.; Sharma, P. Assessing the transferability of machine learning algorithms using cloud computing and earth observation datasets for agricultural land use/cover mapping. Int. Arch. Photogramm. Remote Sens. Spat. Inf. Sci. ISPRS Arch. 2019, 42, 585-592. [CrossRef]

102. Fei, S.W.; Miao, Y.B.; Liu, C.L. Chinese Grain Production Forecasting Method Based on Particle Swarm Optimization-based Support Vector Machine. Recent Patents Eng. 2009, 3, 8-12. [CrossRef] 
103. Gopinath, M.; Batarseh, F.; Beckman, J. Machine Learning in Gravity Models: An Application to Agricultural Trade; Working Paper 27151; National Bureau of Economic Research: Cambridge, MA, USA, 2020. [CrossRef]

104. Yu, H.; Wen, X.; Li, B.; Yang, Z.; Wu, M.; Ma, Y. Uncertainty analysis of artificial intelligence modeling daily reference evapotranspiration in the northwest end of China. Comput. Electron. Agric. 2020, 176, 105653. [CrossRef]

105. Yin, Z.; Feng, Q.; Yang, L.; Deo, R.; Wen, X.; Sim, J.; Xiao, S. Future Projection with an Extreme-Learning Machine and Support Vector Regression of Reference Evapotranspiration in a Mountainous Inland Watershed in North-West China. Water 2017, 9, 880. [CrossRef]

106. Zeman, K.; Rodríguez, L. Quantifying farmer decision-making in an agent-based model. In Proceedings of the 2019 ASABE Annual International Meeting, Boston, MA, USA, 7-10 July 2019.

107. Li, J.; Rodriguez, D.; Tang, X. Effects of land lease policy on changes in land use, mechanization and agricultural pollution. Land Use Policy 2017, 64, 405-413. [CrossRef]

108. Salvini, G.; Ligtenberg, A.; van Paassen, A.; Bregt, A.; Avitabile, V.; Herold, M. REDD+ and climate smart agriculture in landscapes: A case study in Vietnam using companion modelling. J. Environ. Manag. 2016, 172, 58-70. [CrossRef] [PubMed]

109. Francesconi, W.; Pérez Miñana, E.; Willcock, S.; Villa, F.; Quintero, M. Linking ecosystem services to food security in a changing planet: Assessing Peruvian Amazon deforestation using the Artificial Intelligence for Ecosystem Services (ARIES) framework. In Proceedings of the ASABE 1st Climate Change Symposium: Adaptation and Mitigation, Chicago, IL, USA, 3-5 May 2015.

110. Tian, G.; Qiao, Z. Modeling urban expansion policy scenarios using an agent-based approach for Guangzhou Metropolitan Region of China. Ecol. Soc. 2014, 19, 52. [CrossRef]

111. Al-Amin, S.; Berglund, E.; Larson, K. Complex Adaptive System Framework to Simulate Adaptations of Human-Environmental Systems to Climate Change and Urbanization: The Verde River Basin. In Proceedings of the 2014 World Environmental and Water Resources Congress: Water Without Borders, Portland, OR, USA, 1-5 June 2014.

112. Polhill, J.G.; Gimona, A.; Gotts, N. Nonlinearities in biodiversity incentive schemes: A study using an integrated agent-based and metacommunity model. Environ. Model. Softw. 2013, 45, 74-91. [CrossRef]

113. Oliveira, A.; Nero, M. Application of fuzzy logic in prediction of fire in João Pessoa City-Brazil. Commun. Comput. Inf. Sci. 2013, 399, 323-334. [CrossRef]

114. Gimona, A.; Polhill, J. Exploring robustness of biodiversity policy with a coupled meta community and agent-based model. J. Land Use Sci. 2011, 6, 175-193. [CrossRef]

115. Gimona, A.; Polhill, J.; Davies, B. Sinks, sustainability, and conservation incentives. In Sources, Sinks and Sustainability; Liu, J., Hull, V., Morzillo, A.T., Wiens, J.A., Eds.; Cambridge University Press: Cambridge, UK, 2011; pp. 155-178. [CrossRef]

116. Polhill, J.; Gimona, A.; Gotts, N. Analysis of incentive schemes for biodiversity using a coupled agent-based model of land use change and species metacommunity model. In International Environmental Modelling and Software Society (iEMSs) 2010 International Congress on Environmental Modelling and Software, Ottawa, QC, Canada, 5-8 July 2010; Volume 1, pp. 809-816.

117. Berger, T.; Schilling, C.; Troost, C.; Latynskiy, E. Knowledge-brokering with agent-based models: Some experiences from irrigation-related research in Chile. In Proceedings of the 5th Biennial Conference of the International Environmental Modelling and Software Society, iEMSs 2010, Ottawa, QC, Canada, 5-8 July 2010; Volume 1, pp. 791-800.

118. Etienne, M.; Bourgeois, M.; Souchéreb, V. Participatory modelling of fire prevention and urbanisation in southern France: From coconstructing to playing with the model. In Proceedings of the iEMSs 4th Biennial Meeting-International Congress on Environmental Modelling and Software: Integrating Sciences and Information Technology for Environmental Assessment and Decision Making, iEMSs 2008, Barcelona, Catalonia, Spain, 7-10 July 2008; Volume 2, pp. 972-979.

119. Su, X.; Asseng, S.; Campbell, P.; Cook, F.; Schilizzi, S.; Nancarrow, B.; Poole, M.; Carlin, G.; Brockman, H. A conceptual model for simulating farmer decisions and land use change. In Proceedings of the MODSIM05-International Congress on Modelling and Simulation: Advances and Applications for Management and Decision Making, Melbourne, Australia, 12-15 December 2005; pp. 156-161.

120. Pandey, B.; Khare, D. Analyzing and modeling of a large river basin dynamics applying integrated cellular automata and Markov model. Environ. Earth Sci. 2017, 76, 1-12. [CrossRef] 
121. Singh, S.; Mustak, S.; Srivastava, P.; Szabó, S.; Islam, T. Predicting Spatial and Decadal LULC Changes Through Cellular Automata Markov Chain Models Using Earth Observation Datasets and Geo-information. Environ. Process. 2015, 2, 61-78. [CrossRef]

122. Deep, S.; Saklani, A. Urban sprawl modeling using cellular automata. Egypt. J. Remote Sens. Space Sci. 2014, 17, 179-187. [CrossRef]

123. Fürst, C.; Volk, M.; Pietzsch, K.; Makeschin, F. Pimp your landscape: A tool for qualitative evaluation of the effects of regional planning measures on ecosystem services. Environ. Manag. 2010, 46, 953-968. [CrossRef]

124. Van Delden, H. Integration of socio-economic and bio-physical models to support sustainable development. In Proceedings of the 18th World IMACS Congress and MODSIM09 International Congress on Modelling and Simulation: Interfacing Modelling and Simulation with Mathematical and Computational Sciences, Cairns, Australia, 13-17 July 2009; pp. 2457-2463.

125. Feng, Y.; Liu, Y.; Han, Z. Land use simulation and landscape assessment by using genetic algorithm based on cellular automata under different sampling schemes. Chin. J. Appl. Ecol. 2011, 22, 957-963.

126. Portoghese, I.; D’Agostino, D.; Giordano, R.; Scardigno, A.; Apollonio, C.; Vurro, M. An integrated modelling tool to evaluate the acceptability of irrigation constraint measures for groundwater protection. Environ. Model. Softw. 2013, 46, 90-103. [CrossRef]

127. Meisner, M.; Rosenheim, J.; Tagkopoulos, I.; Peters, D. A data-driven, machine learning framework for optimal pest management in cotton. Ecosphere 2016, 7, e01263. [CrossRef]

128. Dhanya, C.; Kumar, D. Data mining for evolution of association rules for droughts and floods in India using climate inputs. J. Geophys. Res. Atmos. 2009, 114, 1-15. [CrossRef]

129. Molina, J.L.; Pulido-Velázquez, M.; Llopis-Albert, C.; Na Haro, S.P. Stochastic hydro-economic model for groundwater quality management using Bayesian networks. Water Sci. Technol. 2013, 67, 579-586. [CrossRef] [PubMed]

130. Tixier, P.; Peyrard, N.; Gaba, S.; Radoszycki, J.; Geoffrey Caron-Lormier, F.V.; Mollot, G.; Sabbadin, R. Modelling interaction networks for enhanced ecosystem services in agroecosystems. Adv. Ecol. Res. Chapter Seven 2013, 49, 437-480. [CrossRef]

131. Yet, B.; Lamanna, C.; Shepherd, K.; Rosenstock, T. Evidence-based investment selection: Prioritizing agricultural development investments under climatic and socio-political risk using Bayesian networks. PLoS ONE 2020, 15, e0234213. [CrossRef]

132. Ali, M.; Deo, R.; Downs, N.; Maraseni, T. Cotton yield prediction with Markov Chain Monte Carlo-based simulation model integrated with genetic programing algorithm: A new hybrid copula-driven approach. Agric. For. Meteorol. 2018, 263, 428-448. [CrossRef]

133. Li, Z.; Nie, C.; Yang, G.; Xu, X.; Jin, X.; Gu, X. Retrieval of LAI and leaf chlorophyll content from remote sensing data by agronomy mechanism knowledge to solve the ill-posed inverse problem. Remote Sens. Agric. Ecosyst. Hydrol. XVI 2014, 9239, 92391Q. [CrossRef]

134. Li, J.; Wang, M. Chaotic Genetic Algorithm-Based Forest Harvest Adjustment. J. Donghua Univ. 2010, 27, 148-151.

135. Wang, M.; Li, J. Adaptive genetic algorithm-based forest harvest adjustment. In Proceedings of the 2008 3rd International Conference on Intelligent System and Knowledge Engineering, ISKE 2008, Xiamen, China, 17-19 November 2008; Volume 1, pp. 541-544. [CrossRef]

136. Nouiri, I.; Yitayew, M.; Maßmann, J.; Tarhouni, J. Multi-objective Optimization Tool for Integrated Groundwater Management. Water Resour. Manag. 2015, 29, 5353-5375. [CrossRef]

137. Fowler, K.; Jenkins, E.; Ostrove, C.; Chrispell, J.; Farthing, M.; Parno, M. A decision making framework with MODFLOW-FMP2 via optimization: Determining trade-offs in crop selection. Environ. Model. Softw. 2015, 69, 280-291. [CrossRef]

138. Zhang, W.; Huang, B. Soil erosion evaluation in a rapidly urbanizing city (Shenzhen, China) and implementation of spatial land-use optimization. Environ. Sci. Pollut. Res. 2015, 22, 4475-4490. [CrossRef]

139. Sterman, J. Business Dynamics: Systems Thinking and Modeling for a Complex World; McGraw-Hill Higher Education, Irwin/McGraw-Hill: New York, NY, USA, 2000; p. 982.

140. Denrell, J.; March, J.G. Adaptation as Information Restriction: The Hot Stove Effect. Organ. Sci. 2001, 12, 523-538. [CrossRef]

141. Ghaffarzadegan, N.; Lyneisb, J.; Richardson, G. How small system dynamics models can help the public policy process. Syst. Dyn. Rev. 2010, 27, 22-44. [CrossRef] 
142. Forrester, J. System Dynamics: The Next Fifty Years. Syst. Dyn. Rev. 2007, 23, 359-370. [CrossRef]

143. Lichtenstein, S.; Fischhoff, B.; Phillips, L. Calibration of probabilities: The state of the art to 1980. In Judgment under Uncertainty: Heuristics and Biases; Tversky, A., Kahneman, D., Slovic, P., Eds.; Cambridge University Press: Cambridge, UK, 1982. [CrossRef]

144. Senge, P.M. The fifth discipline, the art and practice of the learning organization. Perform. Instr. 1991, 30, 37. [CrossRef]

Publisher's Note: MDPI stays neutral with regard to jurisdictional claims in published maps and institutional affiliations.

(C) 2020 by the authors. Licensee MDPI, Basel, Switzerland. This article is an open access article distributed under the terms and conditions of the Creative Commons Attribution (CC BY) license (http:/ / creativecommons.org/licenses/by/4.0/). 